\title{
Potential of Sewage Water to Produce Biogas with Cow Dung
}

\author{
Manpreet Singh ${ }^{1}$, Jagjot Singh ${ }^{2}$ \\ Department of Mechanical Engineering, Ramgariha Institute of Engineering and Technology
}

\begin{abstract}
As the energy of the universe is conserved and it alters from one form to another, a complete and efficient utilization of such energy becomes equally important without affecting the climate properties. The reason behind this reduction is to limit the use of fossil fuels which further leads to a clean and green environment. Therefore, research communities seeing at "Sustainable Renewable Energy Generation and Utilization" as a solution to the next generation technology of generating and consuming energy. Thus, energy communities have found one solution from many of those and well known as Biogas utilization which is a byproduct of biomass. Thus Biogas consists of renewable energy resources which have very less green house potential that makes it very much viable. As municipal solid-waste (MSW) or sewage water (SW) has a high potential to generate biogas (chemical energy) while subjected to microbiological anaerobic digestion process thus it is being widely employed in generating electrical energy in European Continent. Thus keeping this in mind, in this present work an attempt has been made to study the content of methane generated while combining cow dung in sewage water in order to compensate the shortage of raw material in active biogas power plant. Results shows approximately same quantity of biogas has been obtained as plant is attained by using cow dung only. Also, PH, TDS and VS analyses have been done in order to check acidity and alkanity of the mixture before and after the anaerobic digestion.
\end{abstract}

Keywords: Anaerobic Co-Digestion, Biogas, Cow Dung and Sewage Water

\section{Introduction}

Recently in 2014, International Energy Agency (IEA) published Key World Energy Statistics which includes information on the worldwide energy generation, supply and consumption statistics [1] and which shows total Primary Energy Supply (TPES) has been increased by twice from 1971 to 2012 which is a consequence of population explosion and augmentation in the people's living standards. Due to consequence of this, universal challenges like global warming, acid rain etc. have come into picture which limits the usage of fossil fuels in futuristic energy systems. From the energy statistics, it has been noticed that the percentage natural gas and coal production found to decrease significantly from year 1971 to 2013 for the OECD's [1]. The reason behind this reduction is to limit the use of fossil fuels which further leads to a clean and green environment. Energy communities have found one solution from many of those and well known as Biogas utilization which is a byproduct of biomass. Thus Biogas consists of renewable energy resources which have very less green house potential that makes it very much viable. A significant increase in the installation of Biogas Plants has been seen from past some decades in Europe region [2]. The direct benefits of using biogas are: improvement in global warming and reduction in greenhouse gas emissions, waste diminution, flexible and conclusive use of biogas (combined heat and power generation, CHP). European countries are facing massive troubles related with overproduction of macrobiotic wastes from industry, households and agriculture [3]. From the literature, it has been found that municipal solid-waste (MSW) has a high potential to generate biogas (chemical energy) while subjected to microbiological anaerobic digestion process [4-6]. In order to produce biogas from MSW, batch and continuous anaerobic digesters have been designed and can be found elsewhere in [7]. Kiely [8] illustrated that anaerobic digestion is used globally for the treatment of industrial, municipal waste-water and agricultural: he also noted that, in modern years, this principle has also been employed for the treatment of municipal solid-wastes. Vassiliou [9], produced biogas from wastes of raw manure plus wash-water from large livestockfarms, and the wastes from food and drink industries, explained that the second stage of any project should be to generate biogas from the organic components of sourceseparated municipal solid-wastes (MSWs). It has been noticed from the literature that biogas plants using MSWs are widely employed in generating electricity worldwide [10-11]. Abubakar et al. (2012) [12] studied the anaerobic digestion of cow dung for biogas production and they explained that there is a great deal of environmental pressure in many parts of the world to ascertain how livestock waste can best be handled. Livestock manure, like cow dung in the absence of appropriate disposal methods can cause adverse environmental and health problems such as: pathogen contamination, odour, air borne ammonia, green house gases, etc [13]. Anaerobic digestion has been considered as waste-to-energy technology, and is widely used in the treatment of different organic wastes, for example: organic fraction of municipal solid waste, sewage sludge, food waste, animal manure, etc [13].

By considering all the factors reviewed in literature and practical difficulties faced by Biogas Plant Unit on the production of biogas from the animal manure, in this present work, an attempt has been made in order to fulfill the demand of the raw material i.e. cow dung (app. 180tonnes) which was found to be significantly less than the actual demand (235tonnes) by introducing sewage water to a certain extent. By using sewage, the shortage that has been faced by the industry can be fulfilled. The other benefit of using sewage is that the disposal of municipal waste can easily be handled through this concept. One of the main aims of this study is to enhance the effectiveness and the performance characteristics of anaerobic digestion of cow dung for biogas production in batch and semi-continuous operation. It has been observed from the study that 


\section{International Journal of Science and Research (IJSR) \\ ISSN (Online): 2319-7064}

Index Copernicus Value (2015): 78.96 | Impact Factor (2015): 6.391

approximately same amount of methane gas has been recovered through anaerobic digestion.

\section{Methodology}

To produce biogas, an experimental setup has been built inside the biogas plant located containing three reactors (R1, $\mathrm{R} 2$ and R3). Out of three reactors, R1 has been filled with cow dung $(1000 \mathrm{ml}), \mathrm{R} 2$ is filled with mixture of cow dung and sewage water $(\mathrm{SW})$ volumetrically $(1000 \mathrm{ml})$ containing $30 \%$ SW, R3 containing $40 \% \mathrm{SW}$ and R4 containing $50 \%$ $\mathrm{SW}$ in cow dung as a part of batch production of biogas. Generally, bottle-1 has been completely filled with the cow dung (R1) or with mixture of both cow dung and SW (R2, R3 \& R4) is connected with bottle-2 containing $1000 \mathrm{ml}$ of water through flexible pipes in order to collect the biogas by displacing water to bottle-3. Further, in order to test the biogas composition, the sample is extracted from reactor R2, R3 and R4 in a flexible balloon.

Table 1: Ph Analysis

\begin{tabular}{|c|c|c|c|}
\hline \multirow{2}{*}{ Name of Sample } & \multicolumn{2}{|c|}{ PH Value } & \multirow{2}{*}{ Nature after process } \\
\cline { 2 - 3 } & Start & End & \\
\hline $100 \%$ CD & 6.84 & 6.95 & Shift to Alkaline \\
\hline $100 \%$ SW & 7.22 & - & - \\
\hline $30 \%$ SW+70\%CD & 6.25 & 6.37 & Shift to Alkaline \\
\hline $40 \%$ SW+60\%CD & 6.29 & 6.34 & Shift to Alkaline \\
\hline $50 \%$ SW+50\%CD & 6.34 & 6.44 & Shift to Alkaline \\
\hline
\end{tabular}

\section{Results and Discussions}

During the study following tests have been done at the starting and ending of the anaerobic digestion process, named; Ph concentration analysis, Total Dissolved Solids (TDS) analysis, Volatile Suspended Solids (VS) analysis. This analysis is considered to be a mesophilic as temperature of surrounding is kept in between 35 to $45^{\circ} \mathrm{C}$. The results obtained from these analyses are tabulated in the Table 1 and Table 3.

$\mathrm{Ph}$ analysis shows the mixture of sewage water and cow dung showed Alkanity after the completion of the process. The analysis on TDS and VS has been shown in Table 2. Figure 1 shows a comparison of volume of water displaced per day between the reactors (R1, R2, R3 and R4) and it has been observed that on the day 7 to day 9 maximum water is getting displaced which implies the quantity of gas developed in these days is utmost.

\section{a) Quantity of methane}

In order to check the composition of biogas, the test has been conducted in CSIR \& CMERI (Ludhiana) Laboratory and results obtained have been shown in Table 3.

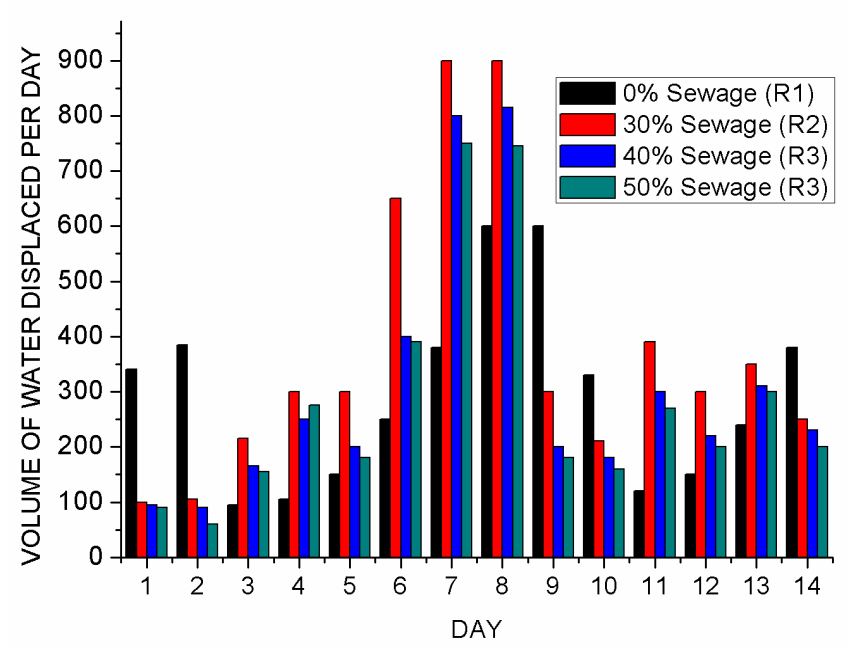

Figure 1: Comparison of Volume of Water Displaced Per Day among Reactors

Table 2: TS \& VS Analysis at Starting and Ending Time

\begin{tabular}{|c|c|c|c|c|c|c|c|c|c|c|c|c|c|c|}
\hline \multirow[t]{2}{*}{$\begin{array}{l}\text { Sr. } \\
\text { No. }\end{array}$} & \multicolumn{2}{|c|}{$\begin{array}{c}\text { Weight of } \\
\text { Cruscible (W1) }\end{array}$} & \multicolumn{2}{|c|}{$\begin{array}{l}\text { Weight of Cruscible } \\
\text { with Filtered Sample } \\
\text { (W2) }\end{array}$} & \multicolumn{2}{|c|}{$\begin{array}{l}\text { Weight after } 2 \\
\text { Hour at } 100^{\circ} \mathrm{C} \\
\text { (W3) }\end{array}$} & \multicolumn{2}{|c|}{$\begin{array}{c}\mathrm{TS}= \\
\underline{\mathrm{W} 3-} \\
\underline{\mathrm{W} 1 \times 100} \\
\mathrm{~W} 2-\mathrm{W} 1(\%)\end{array}$} & \multicolumn{2}{|c|}{$\begin{array}{c}\text { Weight of } \\
\text { Cruscible+Sample } \\
\text { After } 1 \text { Hour At } \\
500^{\wedge} \mathrm{C}(\mathrm{W} 4)\end{array}$} & \multicolumn{2}{|c|}{$\begin{array}{c}\text { Weight of Sample } \\
\text { after } 1 \text { Hour at } 500^{\circ} \mathrm{C} \\
\text { (W3-W4) }\end{array}$} & \multicolumn{2}{|c|}{$\begin{array}{l}\mathrm{VS}=\mathrm{W} 3- \\
\mathrm{W} 4 \mathrm{X} 100 \\
\mathrm{~W} 3-\mathrm{W} 1\end{array}$} \\
\hline & Start & End & Start & End & Start & End & Start & End & Start & End & Start & End & Start & End \\
\hline \multicolumn{15}{|c|}{$30 \%$ SEWAGE and $70 \%$ COWDUNG } \\
\hline 1. & 20.8 & 20.8 & 30.8 & 30.8 & 21.8 & 21.4 & 10 & 6 & 21 & 20.9 & 0.8 & 0.5 & 80 & 83.33 \\
\hline 2. & 21.4 & 21 & 31.4 & 31 & 22.8 & 21.6 & 14 & 6 & 21.7 & 21.1 & 1.1 & 0.5 & 78.57 & 83.33 \\
\hline 3. & 19.2 & 19.2 & 29.2 & 29.2 & 20.2 & 19.8 & 10 & 6 & 19.4 & 19.4 & 0.8 & 0.4 & 80 & 66.66 \\
\hline \multicolumn{15}{|c|}{ 40\% SEWAGE and $60 \%$ COWDUNG } \\
\hline 1. & 21.4 & 21.3 & 31.4 & 31.3 & 23.2 & 21.9 & 18 & 6 & 21.8 & 21.5 & 1.4 & 0.4 & 77.77 & 66.66 \\
\hline 2. & 21 & 20.4 & 31 & 30.4 & 23.2 & 20.8 & 22 & 4 & 21.6 & 20.5 & 1.6 & 0.3 & 72.72 & 75 \\
\hline 3. & 20.4 & 21.4 & 30.4 & 31.4 & 21.7 & 21.7 & 17 & 4 & 20.7 & 21.5 & 1 & 0.3 & 76.90 & 75 \\
\hline \multicolumn{15}{|c|}{$50 \%$ SEWAGE and $50 \%$ COWDUNG } \\
\hline 1. & 21.6 & 21.5 & 31.6 & 31.5 & 22.6 & 21.9 & 10 & 4 & 21.8 & 21.6 & 0.8 & 0.3 & 80 & 75 \\
\hline 2. & 21.9 & 21.2 & 31.9 & 31.2 & 22.8 & 21.6 & 9 & 4 & 22.1 & 21.3 & 0.7 & 0.3 & 77.77 & 75 \\
\hline 3. & 21.6 & 21.9 & 31.6 & 31.9 & 22.6 & 22.3 & 10 & 4 & 21.8 & 22 & 0.8 & 0.3 & 80 & 75 \\
\hline
\end{tabular}

\begin{tabular}{|c|c|c|c|c|c|c|c|c|c|c|c|c|c|c|}
\hline \multicolumn{11}{|c|}{$100 \%$ COWDUNG } \\
\hline 1. & 21.9 & 21.2 & 31.9 & 31.2 & 22.7 & 21.9 & 8 & 7 & 22 & 21.3 & 0.7 & 0.6 & 87.5 & 85.71 \\
\hline 2. & 21.3 & 20.9 & 31.3 & 30.9 & 22.2 & 21.7 & 9 & 8 & 21.6 & 21.1 & 0.6 & 0.6 & 66.66 & 75 \\
\hline 3. & 20.9 & 21.9 & 30.9 & 31.9 & 21.7 & 22.7 & 8 & 8 & 21.1 & 22 & 0.6 & 0.7 & 75 & 87.5 \\
\hline
\end{tabular}




\section{International Journal of Science and Research (IJSR) \\ ISSN (Online): 2319-7064}

Index Copernicus Value (2015): 78.96 | Impact Factor (2015): 6.391

Table 3: Composition of biogas

\begin{tabular}{|c|c|c|}
\hline $\begin{array}{c}\text { Methane \& } \mathrm{CO}_{2} \text { contents of a Bio Gas } \\
\text { (Through Gas Chromatography) }\end{array}$ & $\begin{array}{c}\text { Methane } \\
(\%)\end{array}$ & $\begin{array}{c}\mathrm{CO}_{2} \\
(\%)\end{array}$ \\
\hline Sample 1, 0\% Sewage & 60.56 & 39.43 \\
\hline Sample 2, 30\% Sewage & 48.45 & 25.29 \\
\hline Sample 3, 40\% Sewage & 47.21 & 26.66 \\
\hline Sample 4, 50\% Sewage & 46.04 & 25.94 \\
\hline
\end{tabular}

\section{Conclusions}

From the study it has been concluded that as cow dung has adverse effects on the environment after the digestion process so it may beneficial when sewage water has been added to it. One thing is sure that sewage water mixing in cow dung will lead to match the demand that is being required at the power plant. From Table 3, it can be seen that as the quantity of sewage water increased, methane content is found to decrease and for the optimum concentration of SW further studies are required.

\section{References}

[1] Key World Energy Statistics, The International Energy Agency 2013.

[2] http://european-biogas.eu/2014/12/16/4331/ assessed on 12 May, 2016.

[3] Xie Sihaung, Zhan Xinmin, Lawlor Peadar G., "Evaluation of Biogas Production from Anaerobic Digestion of Pig Manure and Grass Silage" a PhD. dissertation submitted to the National University of Ireland, October 2012.

[4] Igoni AH, Eze CL, Ayotamuno MJ, Abowei MFN "Potentials of biogas generation from municipal solidwaste in the Port Harcourt Metropolis" Proceedings of the 1st annual conference of Science and Technology Forum, vol. 1(2). Uyo, Nigeria; 2005. pp. 67-72.

[5] Forster-Carneiro, "Dry thermophilic anaerobic digestion of organic fraction of the municipal solid waste: focusing on the inoculum sources" University of Cadiz.

[6] Martin, "Anaerobic co-digestion of the organic fraction of municipal solid waste with FOG waste from a sewage treatment plant: Recovering a wasted methane potential and enhancing the biogas yield", Departament d'Enginyeria Química, Universitat Autònoma de Barcelona, 08193 Bellaterra, Spain.

[7] Igoni AH. "Design of Anaerobic bio-reactors for the simulation of biogas production from municipal solidwaste" Ph.D. Thesis of the Rivers State University of Science and Technology, Port Harcourt, Nigeria; 2006. p. 261.

[8] Kiely G. Environmental Engineering. International ed. Boston: Irwin, McGraw-Hill; 1998, p. 979.

[9] Vassiliou N. The biogas project of Cyprus. Proceedings of the 1st international conference of Energy and the Environment. Limassol, Cyprus; 1997. pp. 757-761.

[10] Xuereb P. Biogas - a fuel produced from waste, <http://www.synapse.net.mt/mirin/newsletter/3836.asp/> ; 1997.

[11] Tchobanoglous G, Burton FL. Waste-water Engineering: treatment disposal and reuse. 3rd ed. New York: McGraw-Hill; 1991, p.1334.

[12] Baba Shehu Umar Ibn Abubakar, Nasir Ismail, "Anaerobic Digestion of Cow Dung for Biogas
Production" ARPN Journal of Engineering and Applied Sciences, ISSN 1819-6608, VOL. 7, NO. 2, FEBRUARY 2012.

[13] Biogas Handbook, ISBN 978-87-992962-0-0, Published by University of Southern Denmark Esbjerg, Niels Bohrs Vej 9-10, DK-6700 Esbjerg, Denmark. 